\title{
Scaling of Reference Reach for Desired Bankfull Discharge
}

\author{
Bruce M. McEnroe, C. Bryan Young, John E. Shelley \\ Department of Civil, Environmental and Architectural Engineering, University of Kansas, Lawrence, USA \\ Email: cbyoung@ku.edu
}

Received 16 January 2014; revised 14 February 2014; accepted 12 March 2014

Copyright @ 2014 by authors and Scientific Research Publishing Inc.

This work is licensed under the Creative Commons Attribution International License (CC BY). http://creativecommons.org/licenses/by/4.0/

c) (i) Open Access

\begin{abstract}
The reference reach method is commonly used for natural stream design. In the reference reach approach, a stable reach is selected to serve as the design template for a design reach. The planform and profile of this reference reach must be scaled to fit the design site. Currently, the leading method for scaling uses a simple ratio of cross-sectional areas. This paper presents a simple method that employs hydraulic scaling to size the design reach to accommodate the desired bankfull flow. The method introduced in this paper is easy to use, does not require additional survey data, and should lead to more robust channel design.
\end{abstract}

\section{Keywords}

\section{Channel Design, Restoration, Streams, Stream Improvement}

\section{Introduction}

The reference-reach approach to stream restoration design involves the scaling of cross-sectional and planform dimensions from an unimpaired section of stream (i.e., the reference reach). This approach to natural stream design was first developed by Rosgen, whose design method "has been implemented in many locations and is cited as the methodology of choice by several state and local governments” in the United States [1]. Rosgen's design method differs from the two other common approaches to natural channel design (analytical and hydraulic geometry methods) [2]-[4] in an important regard: the channel is not designed to convey a specific bankfull discharge. The reference reach can be a stable, unimpaired reach on the same stream as the design reach, or can be selected from a stable stream in the same hydro-physiographic region. Care should be taken to select a reference reach from a stream that has similar characteristics to the design reach with respect to channel capacity, crosssection, planform, sinuosity, and bed material.

In the reference reach approach to stream restoration design, key linear dimensions of the reference reach are 
multiplied by a scaling factor, $\alpha$, to obtain the corresponding dimensions of the design reach [1]. These dimensions include the widths and depths of bankfull cross-sections at riffles and pools, and wavelengths, amplitudes and radii of curvature of meander bends.

This paper presents a new scaling method that yields a design (restoration) reach with a desired bankfull discharge. The scaling factor is obtained from a simple formula that includes the bankfull discharge as an input. This method does not require an estimate of the bankfull discharge for the reference reach.

\section{Rosgen's Scaling Method}

In Rosgen's design method [1], the first channel dimension to be determined is the bankfull cross-sectional area at a typical riffle section, $A_{d}$. Note that the subscript $d$ refers to the design reach, while the subscript $r$ refers to the reference reach. In Rosgen's method, the cross-sectional area for the design reach is obtained from a regional curve that relates $A_{d}$ to drainage area for streams within the hydro-physiographic region of interest. Next, the bankfull width at the riffle, $W_{d}$, is computed with the formula:

$$
W_{d}=\sqrt{\frac{W_{r}}{D_{r}} A_{d}}
$$

in which $W_{r}$ and $D_{r}$ are the bankfull width and mean depth at a selected riffle in the reference reach. The mean depth, $D_{r}$, is defined as $A_{r} / W_{r}$. By substituting $A_{r} / W_{r}$ for $D_{r}$, Equation (1) can be restated in the form:

$$
W_{d}=\sqrt{\frac{A_{d}}{A_{r}}} W_{r}
$$

Equation (2) shows that that $\left(A_{d} / A_{r}\right)^{1 / 2}$ is the scaling factor applied to $W_{r}$ to obtain $W_{d}$. In subsequent steps, other key cross-sectional and planform dimensions are scaled by the ratio $W_{d} / W_{r}$, which equals $\left(A_{d} / A_{r}\right)^{1 / 2}$. Therefore, the scaling factor, $\alpha$, for Rosgen's design method is:

$$
\alpha=\sqrt{\frac{A_{d}}{A_{r}}}
$$

with $A_{d}$ obtained from a regional curve that relates cross-sectional area to drainage area.

\section{Scaling for Desired Bankfull Discharge}

Bankfull discharge is an important consideration in stream restoration design. The usual objective is a bankfull capacity that would be typical of a natural stream with similar watershed characteristics in the same region. The natural bankfull discharge is estimated either from a hydraulic analysis of an unimpaired reach upstream or downstream of the restoration reach, or from a regional regression model that relates natural bankfull discharge to watershed characteristics [5].

Once an appropriate bankfull discharge has been determined, the primary unknowns are the average bed slope of the design reach and the scaling factor to be applied to the reference reach dimensions. The bankfull discharge can be related to the average bed slope and cross-sectional dimensions at a representative riffle section by the Manning hydraulic resistance formula:

$$
Q_{d}=\frac{C}{n_{d}} \frac{A_{d}^{5 / 3}}{P_{d}^{2 / 3}} \sqrt{S_{d}}
$$

in which $Q_{d}$ is the bankfull discharge, $n_{d}$ is the Manning resistance coefficient, $c$ is a units-related constant ( 1 for SI units; 1.49 for US customary units), $P_{d}$ is the wetted perimeter and $S_{d}$ is the average bed slope (the subscript d indicates the design reach).

The average bed slope depends on the channel's sinuosity, $k$, defined as the ratio of the stream length to the valley length. The stream length, $S L$, is measured along the channel thalweg; the valley length, $V L$, is measured along a non-meandering path on the valley alignment. The average bed slope of the design reach can be written in terms of the sinuosity, $k_{d}$; the valley length, $V L_{d}$; and the total fall in the bed elevation through the reach, $F_{d}$ :

$$
S_{d}=\frac{F_{d}}{k_{d} \cdot V L_{d}}
$$


The valley length and the total fall in the bed elevation are fixed, measurable quantities. If the design reach were an exactly scaled copy of the reference reach, its sinuosity would exactly equal the sinuosity of the reference reach, $k_{r}$. In practice, the scaled planform of the reference reach must be adjusted somewhat to fit the constraints of the restoration site. However, a reasonable design objective is to match the overall sinuosity of the reference reach: $k_{d}=k_{r}$. Our scaling method imposes this requirement, which allows $S_{d}$ to be determined independently of the scaling factor.

The cross-sectional area and wetted perimeter of the design reach can be expressed in terms of the corresponding dimensions of the reference reach and the linear scaling factor as follows:

$$
\begin{gathered}
P_{d}=\alpha P_{r} \\
A_{d}=\alpha^{2} A_{r}
\end{gathered}
$$

Substituting $\alpha^{2} A_{r}$ for $A_{d}$ and $\alpha \cdot P_{r}$ for $P_{d}$ in Equation (4) and solving for $\alpha$ leads to the following equation for the scaling factor:

$$
\alpha=\left(\frac{Q_{d} n_{d}}{c \sqrt{S_{d}}} \frac{P_{r}^{2 / 3}}{A_{r}^{5 / 3}}\right)^{3 / 8}
$$

Linear dimensions of the reference reach's cross-section and planform are multiplied by this scaling factor to obtain the corresponding dimensions of the reference reach. It should be noted that this scaling method makes use of data that would typically be collected as part of a morphological description [6] and is compatible with other aspects of Rosgen's reference reach method [1].

\section{Conclusion}

The simple scaling method presented here yields a design reach that conveys the desired bankfull discharge. As such, this approach should lead to more robust channel design using a reference reach method. Our method does not account for sediment transport and instead relies on the careful selection of a reference reach that matches the general channel characteristics of the design reach, including bed and bank sediment. Analytical methods do exist to design a channel reach to convey the bankfull flow and sediment load [4]. The scaling method presented here, however, is intended to improve upon Rosgen's [1] popular reference reach approach.

\section{Acknowledgements}

This work was sponsored by the Kansas Department of Transportation (KDOT) through the Kansas Transportation Research and New Developments (K-TRAN) Program.

\section{References}

[1] Rosgen, D.L. (2007) Rosgen Geomorphic Channel Design. National Engineering Handbook, Part 654, Stream Restoration Design, Natural Resources Conservation Service.

[2] Soar, P.J. and Thorne, C.R. (2001) Channel Restoration Design for Meandering Rivers. Coastal and Hydraulics Laboratory, US Army Engineer Research and Development Center, Vicksburg.

[3] Copeland, R.R., McComas, D.N., Thorne, C.R., Soar, P.J. and Jonas, M.M. (2001) Hydraulic Design of Stream Restoration Projects. Coastal and Hydraulics Laboratory, US Army Engineer Research and Development Center, Vicksburg.

[4] McEnroe, B.M., Young, C.B. and Shelley, J.E. (2008) Guidelines for Stream Realignment Design. Kansas Department of Transportation.

[5] Shelley, J., Young, C. and McEnroe, B. (2009) Bankfull Discharge for Kansas Natural Alluvial Channel Design. Proceedings of the World Environment and Water Resources Congress 2009, 3609-3614. http://dx.doi.org/10.1061/41036(342)364

[6] Rosgen, D.L. and Silvey, H.L. (1996) Applied River Morphology. Wildland Hydrology, Pagosa Springs, Colorado. 